\title{
Editorial
}

\section{Impaired NK Cell Function in ESRD Patients}

\section{Gerhard Lonnemann}

Centre of Nephrology and Hemodialysis, Langenhagen, Germany

In this issue of Blood Purification, an interesting work by Eleftheriadis et al. is published on a new aspect of impaired function of natural killer (NK) cells in chronic hemodialysis patients. The authors demonstrate that compared to healthy controls, patients on chronic hemodialysis treatment have a normal number of lymphocytes and NK cells, but decreased NK cell activity as indicated by decreased expression of the $\zeta$-chain on NK cells, which is an early marker of NK cell activation [1]. Since plasma levels of the proinflammatory cytokines IL- 6 and TNF- $\alpha$ as well as C-reactive protein are elevated in hemodialysis patients, it is concluded that chronic inflammation and preactivation of monocytes could be responsible for the impaired function of NK cells.

Impaired NK cell function is one of the aspects in the well-known but only partially explained immunodeficiency of uremic patients involving both the T-cell- and the B-cell-dependent immune response. The first step in the reaction to foreign antigens is adequate recognition by the circulating monocyte-derived dendritic cells, also called antigen-presenting cells (APC). Antigen processing by the APC has to be followed by the presentation of the processed antigen to the T-helper cell via the interaction of the major histocompatibility complex (MHC) on the APC and the T-cell receptor on the T-helper cell, accompanied by the secretion of co-stimulatory cytokines such as IL-4, IL-12 and IL-18. Depending on the antigen, this process leads to an IL-4-dependent activation of Thelper 2 (Th2) cells, production of IL-5 and IL-10 and the stimulation of B cells to produce the specific antibodies

\section{KARGER}

Fax +41613061234

E-Mail karger@karger.ch

www.karger.com
(C) 2008 S. Karger AG, Basel

0253-5068/08/0264-0315\$24.50/0

Accessible online at:

www.karger.com/bpu (humoral immune response). Alternatively, if IL-12 and IL-18 are predominant, a Th1 response is initiated leading to the secretion of IL- 2 and interferon- $\gamma($ IFN- $\gamma$ ) and the stimulation of cytotoxic T cells and NK cells (cellular immune response).

Several studies in patients with ESRD demonstrated the preactivation of circulating monocytes $[2,3]$. The Th1 response may be disturbed on the level of antigen presentation by the APC, on the level of IL-12- and IL-18-dependent activation of T-helper 1 cells to produce IFN- $\gamma$, which is the key cytokine to activate NK cells [4]. The IFN- $\gamma$ production is impaired in ESRD patients compared to healthy controls, although the secretion of IL-18 ('IFN- $\gamma$-inducing factor') is normal or even increased [5]. The disturbance of acquired immunity in ESRD patients more likely occurs on the level of APC-T-cell interaction. The expression of the co-stimulatory molecule B7-2 (CD86) on APC is downregulated in ESRD patients [6]. More recent studies demonstrate that uremic serum containing high concentrations of urea and other undefined uremic toxins impairs APC maturation, proliferation and function [7]. One important uremic toxin is $\beta_{2}$-microglobulin, which has been shown to inhibit the generation of functional APC in high concentrations ( $>10 \mathrm{mg} / \mathrm{l})$ [8]. Better removal of uremic toxins by intensified hemodialysis procedures using longer treatment times and high-flux membranes may improve the function of APC leading to an adequate immune response and NK cell activation [7]. With respect to the impaired secretion of IFN- $\gamma$, it has been demonstrated that compared to low-
Gerhard Lonnemann, MD

Centre of Nephrology and Hemodialysis

Eickenhof 15, DE-30851 Langenhagen (Germany)

Tel. +49511786 560, Fax +495117865625

E-Mail Lonnemann@eickenhof-dialyse.de 
flux hemodialysis, the switch to high-flux membranes reduces the resting levels of $\beta_{2}$-microglobulin by $25-30 \%$, and this was accompanied by a significant increase in IFN- $\gamma$ production, which was then no longer different from normal controls [9].

In conclusion, acquired immunity in ESRD patients is disturbed in several aspects starting with the impaired maturation of APC and ending in the downregulated ac- tivation of NK cells. Uremic toxins including $\beta_{2}$-microglobulin play an important role leading to the option to improve T-cell function in ESRD patients by employing high-flux hemodialysis [10]. It remains to be shown whether high-flux dialysis has an impact on the rate of infections, inflammatory diseases and outcome in ESRD patients.

\section{References}

1 Eleftheriadis T, Kartsios C, Yiannaki E, et al: Chronic inflammation and CD16+ NK-cell $\zeta$-chain downregulation in hemodialysis patients. Blood Purif 2008;26:317-321.

-2 Schindler R, Linnenweber S, Schulze M, et al: Gene expression of interleukin-1 $\beta$ during hemodialysis. Kidney Int 1993;43:712-721.

-3 Girndt M, Köhler H, Schiedhelm-Weick E, et al: Production of interleukin-6, tumor necrosis factor- $\alpha$ and interleukin-10 in vitro correlates with clinical immune defect in chronic hemodialysis patients. Kidney Int 1995;47:559-565.

4 Dinarello CA: Interleukin-18 and the pathogenesis of inflammatory diseases. Semin Nephrol 2007;27:98-114.
Lonnemann G, Novick D, Rubinstein M, Dinarello CA: Interleukin-18, interleukin-18 binding protein and impaired production of interferon- $\gamma$ in chronic renal failure. Clin Nephrol 2003;60:327-334.

6 Girndt M, Sester M, Sester U, et al: Defective expression of B7-2 (CD86) on monocytes of dialysis patients correlates to the uremia-associated immune defect. Kidney Int 2001;59: 1382-1389.

7 Lim WH, Kireta S, Russ GR, Coates PT: Uremia impairs blood dendritic cell function in hemodialysis patients. Kidney Int 2007;71: 1122-1131.
8 Xie J, Wang Y, Freeman III ME, et al: Beta-2microglobulin as a negative regulator of the immune system: high concentrations of the protein inhibit in vitro generation of functional dendritic cells. Blood 2003;101:40054012.

9 Lonnemann G, Novick D, Rubinstein M, et al: A switch to high-flux helixone membranes reverses suppressed interferon- $\gamma$ production in patients on low-flux dialysis. Blood Purif 2003;21:225-231.

10 Ronco C, Levin NW: End-stage renal disease: a slowly progressive systemic inflammatory response syndrome; in Ronco C, La Greca G (eds): Contrib Nephrol. Basel, Karger, 2002, vol 137, pp 397-385. 